\title{
ANALISIS PEMAHAMAN KONSEP LIMIT DITINJAU DARI GAYA BELAJAR INTERPERSONAL
}

\author{
${ }^{1}$ Ani Wijayanti, ${ }^{2}$ Prahesti Tirta Safitri, ${ }^{3}$ Aji Raditya \\ ${ }_{1,2,3}$ Universitas Muhammadiyah Tangerang \\ e-mail: wasiyanani@gmail.com
}

\begin{abstract}
Abstrak
Penelitian ini bertujuan untuk mengetahui kemampuan siswa dalam memahami konsep limit yang ditinjau dari gaya belajar interpersonal pada siswa kelas XI IPA SMA Az-Zamir. Jenis penelitian ini adalah penelitian deskriptif. Subjek penelitian adalah guru dan siswa kelas XI IPA SMA Az-Zamir. Objek penelitian adalah kemampuan pemahaman konsep limit dan gaya belajar interpersonal pada siswa. Setting penelitian mengambil tempat XI IPA SMA AZ-Zamir. Metode yang digunakan dalam mengumpulkan data yaitu dengan melakukan obeservasi, angket, tes soal, wawancara serta dokumentasi. Analisis data dilakukan dengan menggunakan analisis kualitatif. Hasil penelitian menunjukan bahwa gaya belajar interpersonal pada siswa berada dalam kategori tinggi dan sedang. Dalam kategori ini siswa tersebut memiliki tingkat gaya belajar interpersonal yang berbeda. Penelitian mengambil 6 sampel yang akan diuji yaitu 3 siswa dengan tingkat gaya belajar interpersonal tinggi yaitu AD, AN, IS dan 3 siswa dengan tingkat gaya belajar interpersonal sedanga yaitu SA, PRS dan TLV. Tidak semua siswa degan tingkat gaya belajar interpesonal tinggi mampu memahami konsep limit.
\end{abstract}

Kata Kunci: Pemahaman Konsep limit dan gaya belajar interpersonal

\begin{abstract}
This study aims to determine the ability of students in understanding the concept of limit interms of interpersonal learning styles instudents of grade XI IPA SMA Az-Zamir. The type of this research is descriptive research. The subjects of this study are teachers and students of grade XI IPA SMA Az-Zamir. The object of this study is the ability to understand the concept of limits and interpersonal learning styles in students. The research setting takes place XI IPA SMA Az-Zamir. The method used in colecting data is by making observations, questionnaires, test questions, interviews, and documentation. Data analysis was done by using qualitative analysis. The results showed that the interpersonal learning style in students was in the high and medium category. In this category these students have different levels of interpersonal learning style that is AD, AN, IS and 3 student with medium levels of interpersonal learning style that is SA, PRS, and TLV. Notall students with high interpersonal learning style are able to understand the concepts of limit.
\end{abstract}

Keywords: Understanding Limit Concepts and Interpersonal Learning Style

\section{PENDAHULUAN}

Matematika adalah salah satu ilmu dasar ilmudasar,baik aspek tatapan maupun aspek penalarannya mempunyai peranan penting dalam upaya penguasaan ilmu dan teknologi. Matematikajugadapatdijadikanbekal untuk terjun dan bersosialisasidalam masyarakat.Misalnyaorangyangtelah mempelajari matematika diharapkan bisa menyerap informasi secara lebih rasional dan berfikir secara logis untuk menghadapi situasi dalam masyarakat. Oleh karena itu matematika perlu diajarkan pada semua jenjang pendidikan muali dari SD sampai perguruan tinggi.

Matematika sendiri merupakan ilmu tetang pola dan urutan (wale, 2008). Matematika juga mencakup tiga elemen menurut Lerner (dalam Rahman, 2003) diantaranya 1) konsep; 2) Keterampilan; 
3) Pemecahan masalah. Piaget (wale, 2008) menyatakan bahwa konsep matematika berisi hubunganhubungan logis yang terdapat kontruksi didalamua dan yang ada didalam pikiran sebagai bagian dari jaringan ide. Dalam pelajaran matematika siswa dituntu agar dapat menguasai konsep dengan baik, karena setiap konsep dari materi matematika saling memiliki keterkaitan yang erat.

Pemahaman konsep merupakan awal untuk memahami keberlanjutan materi yang dipelajari, pemahaman konsep juga merupakan dasar landasan yang penting untuk berfikir supaya dapat menyelesaikan permasalahan dikehidupan nyata. Sebelum siswa menguasai konsep dasar, setiap siswa sudah mempunyai konsep awal (prakonsep) yaitu melalui pengalaman dan pembelajaran yang sudah didapat sebelumnya. Konsep awal ini sangat penting untuk ditanamkan pada materi limit.

Limit fungsi ini merupakan bahan yang akan penulis teliti. Menurut peneliti, Konsep limit fungsi dalah konsep abstrak yang hanya berupa simbol $\lim _{x \rightarrow c} f(x)$ dimana nilai $f(x)$ semakin dekat dengan hasil pada waktu mendekati. Hal tersebut menyebabkan sebagian besar siswa belum mampu memahami apa itu konsep limit fungsi.

Siswa akan mampu memahami konsep limit funsi dengan belajar sesuai dengan gaya belajar mereka. Setiap siswa memiliki gaya belajar untuk membantu mereka dalam menyelesaikan masalah matematika. Tidak sedikit siswa meresa kesulitan ketika mereka tidak bisa belajar dengan gaya belajar yang mereka miliki.

Dalam proses belajar matematika tidak hanya sekedar menghitung dengan rumus matematika atau penggunaan logika, tetapi lebih dari itu. Tidak semua materi dalam matematika bisa dipecahkan oleh individu secara personal, terkadang kita membutuhkan orang lain untuk menjelaskan terkait materi tersebut. Salah satunya adalah guru atau teman kita. Untuk saling memahami dalam menjalin hubungan tidaklah mudah, tidak semua orang mampu memahami secara baik individu lain. Untuk menciptakan hubungan yang baik itulah diperlukan kemampuan yang berasal dari gaya belajar interpersonal. Dengan memahami gaya belajar interpersonal akan membantu kita dalam proses mempelajari matematika pada materi limit fungsi.

Pengertian pemahaman konsep matematika dijelaskan oleh (Murizal, Yarman, Yerizon,2012,19) Pemahaman konsep matematis merupakan salah satu tujuan dari setiap materi yang disampaikan oleh guru, sebab guru merupakan pembimbing siswa untuk mencapai konsep yang diharapkan. Siswa dapat mengusai materi apabila siswa tersebut memahami konsepnya. Dari konsep tersebut siswa belajar bagaimana cara memahami pelajaran dengan baik.

Prima, Vol. 1, No. 1, Juli 2017, 157-173. 
Pemahaman konsep matematika menurut Padma Mike Putri M,Mukhni, Irwan $(2012,68)$ Pemahaman konsep merupakan salah satu indikator penting dikuasai siswa untuk mempelajari matematika selanjutnya yaitu pemecahan masalah dan komunikasi. Dalam mempelajari matekatika siswa dapat menyelesaikan masalah dan dapat berkomunikasi. Dalam mempelajari matematika siswa harus mampu memahami konsepnya.

Pemahaman konsep matematika merupakan suatu hal terpenting untuk siswa dalam memahami matematika serta mampu menuangkan kembali konsep matematika yang lebih sederhana. Siswa dituntut agar dapat memahami konsep matematika. Setiap siswa memiliki kemampuan yang berbeda dalam memahami konsep matematika tergantung dengan gaya belajar mereka.

Indikator pemahaman menurut (Rohmah, 2016, 13) adalah sebagai berikut:

1. Menyatakan ulang konsep yangtelahdipelajari,

2. Mengklasifikasikan objek-objek berdasarkan konsep matematika,

3. Menerapkan konsep secara algoritma,memberikancontoh atau kontra contoh dari konsepyangdipelajari,

4. Menyajikan konsep dalam berbagaibentukrepresentasi,

5. Mengaitkan berbagaikonsep matematika secara internal ataueksternal,

6. Mengembangkansyaratperlu dan/atausyaratcukupsuatu konsep.

Konsep limit fungsi adalah konsep yang abstrak dan hanya menyediakan simbol $\lim _{x \rightarrow a} f(x)$ sehingga tidak dapat dilihat secara langsung bagaimana bentuk dan maksud sebenarnya dari konsep limit fungsi.

Tabel 1.1

Kesesuaian indikator pembelajaran dan indikator pemahaman konsep

\begin{tabular}{|l|l|}
\hline \multicolumn{2}{|c|}{ Konsep Limit } \\
\hline \multicolumn{1}{|c|}{ Indikator pemahaman Konsep } & \multicolumn{1}{c|}{ Indikator Pencapaian } \\
\hline Menyatakan ulang sebuahkonsep & $\begin{array}{l}\text { Siswa dapat menyatakan Konsep } \\
\text { matematika yang mendasari } \\
\text { jawaban yang diberikan. }\end{array}$ \\
\hline $\begin{array}{l}\text { Mengklasifikasi objek-objek } \\
\text { menurut sifatsifat tertentu (sesuai } \\
\text { dengan konsepnya) }\end{array}$ & $\begin{array}{l}\text { Siswa dapat Membuktikan suatu } \\
\text { masalah dalam penyelesaian } \\
\text { matematika }\end{array}$ \\
\hline $\begin{array}{l}\text { Mengaplikasikan konsep atau } \\
\text { algoritma pemecahan masalah }\end{array}$ & $\begin{array}{l}\text { Siswa dapat mengaplikasikan } \\
\text { konsep limit dalam pemecahan } \\
\text { masalah dengan langkah-langkah } \\
\text { yang benar }\end{array}$ \\
\hline
\end{tabular}

\section{Gaya Belajar Interpersonal}

Dalam menyusun pembelajaran matematika diperlukan suatu strategi yang cocok agar tujuan pembelajaran matematika bisa tercapai dengan maksimal. Dalam menentukan strategi 
yang cocok sebaiknya melihat sejauh mana perbedaan siswa dalam memanfaatkan gaya belajar yang dimilikinya dalam proses belajar dapat berlangsung dengan baik.

Gaya belajar yang dikemukakan oleh (Hartati,2016,225) Gaya belajar merupakan cara seseorang untuk menyerap, mengatur dan mengolah bahan informasi atau bahan pelajaran. Dalam merespon stimulus/informasi, ada siswa yang senang merespon informasi sendiri, tetapi ada pula siswa yang merespon informasi secara bersama-sama membentuk kelompok. Siswa yang mempunyai gaya belajar mandiri berusaha menyelesaikan masalahnya sendiri. Dengan demikian siswa tersebut dapat lebih termotivasi dalam belajar sehingga hasil belajarnya akan lebih baik.

Setiap siswa memiliki kemampuan untuk mengembangkan gaya belajar dalam memahami konsep limit. (Silver, Brunsting, Walsh, \& Thomas, 2013), untuk memberikan kesempatan yang sama kepada setiap siswa untuk berhasil merupakan suatu tantangan besar, dimana kita harus mampu memberikan penilaian mengenai apa mereka tahu dan bisa dilakukan. Dalam belajar matematika, siswa memiliki kemampuan dan motivasi yang berbeda, termasuk gaya belajarnya. Terdapat empat gaya belajar matematika siswa, yaitu : 1) Gaya Penguasaan; 2) Gaya Pemahaman; 3) Gaya Interpersonal; dan 4)Gaya Ekspresi Diri.

Gaya belajar adalah bagaimana sebuah informasi diterima dengan baik oleh siswa. Berdasarkan penelitian yang dilakukan oleh Dr. Howard Gardner, ternyata gaya belajar siswa tercermin dari kecenderungan kecerdasan yang dimiliki oleh siswa tersebut.

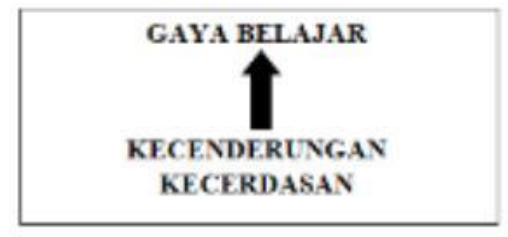

Gambar 1.1 Cerminan Gaya belajar

Multiple Intelegences Research (MIR) adalah instrumen riset yang dapat memberikan deskripsi tentang kecenderungan kecerdasan seseorang. Dari analisis terhadap kecenderungan kecerdasan tersebut, dapat disimpulkan gaya belajar terbaik bagi seseorang. Gaya belajar disini diartikan dengan cara dan pola bagaimana sebuah informasi dapat dengan baik dan sukses diterima oleh otak seseorang.

Gaya belajar interpersonal menurut (Ferriman:2013) adalah these people are the ones who enjoy learning in groups or with other people, and aim to work with others as much as possible. Dalam bahasa Indonesia dinyatakan bahwa gaya belajar interpersonal adalah gaya belajar dimana orang-orang senang belajar berkelompok atau dengan orang lain, dan bertujuan untuk bekerja dengan orang lain sebanyak mungkin. Gaya belajar interpersonal dimana siswa 
lebih aktif dalam belajar kelompok dibanding belajar mandiri. Gaya belajar interpersonal dapat dilihat dari cara siswa berinteraksi dengan teman maupun guru. Siswa dengan gaya belajar interpersonal mudah untuk bergaul, berkolaborasi, bertukar pikiran.

Gaya belajar interpersonal atau gaya belajar antar pribadi, sama dengan kecerdasan antar pribadi (interpersonal). Jadi ketika siswa mempunyai kecerdasan interpersonal, maka siswa tersebut akan belajar dengan gaya belajar interpersonal. Hal tersebut dapat dilihat dari pendapat (Ferriman :2013) yang menjelaskan tentang gaya belajar interpersonal, serta beberapa karakteristik gaya belajar interpersonal sama dengan karakteristik kecerdasan interpersonal. Ketika siswa memiliki kecerdasan interpersonal maka siswa tersebut cenderung memiliki gaya belajar interpersonal.

\section{Karakteristik Gaya Belajar Interpersonal}

Gaya belajar interpersonal memiliki beberapa karakteristik dalam belajar matematika, diantaranya:

1. Ingin mempelajari matematika melalui dialog, kolaborasi dan pembelajaran kooperatif

2. Menyukai masalah matematika yang berfokus pada penerapan di dunia nyata, dan tentang bagaimana matematika dapat membantu orang menyelesaikan persoalan.

3. Menerapkan pendekatan pemecahan masalah dengan diskusi terbuka antar komunitas yang akan menyelesaikan masalah.

4. Mengalami kesulitan ketika pelajaran berfokus pada kerja mandiri, atau ketika penerapan soal di dunia nyata kurang.

5. Belajar dengan baik ketika guru memberi perhatian kepada siswa yang pandai dan gigih dalam belajar matematika.

\section{Hubungan Gaya Belajar Interpersonal dengan Kecerdasan Interpersonal}

Untuk memperjelas terdapat hubungan antara gaya belajar dengan kecerdasan, penelitin akan menunjukan persamaan karakteristik gaya belajar dan kecerdasan secara umum. Hal ini akan menunjukan bahwa terdapat hubungan antara gaya belajar interpersonal dengan kecerdasan interpersonal.

Tabel 1.2

Hubungan gaya belajar interpersonal dengan kecerdasan interpersonal

\begin{tabular}{|c|c|}
\hline Gaya belajar interpersonal & Kecerdasan interpersonal \\
\hline $\begin{array}{l}\text { 1. } \\
\text { Dapat berkomunikasi dengan } \\
\text { baik dengan orangorang, baik } \\
\text { secara lisan dan nonverbal }\end{array}$ & $\begin{array}{c}\text { 1. Pintar bernegosiasi, berhubungan } \\
\text { serta membaca pikiran dan maksud } \\
\text { hati oranglai }\end{array}$ \\
\hline $\begin{array}{l}\text { Lebih memilih belajar di } \\
\text { kelompok atau kelas }\end{array}$ & $\begin{array}{l}\text { 2. Suka berteman, dan melakukan } \\
\text { kegiatan bersama }\end{array}$ \\
\hline
\end{tabular}




\begin{tabular}{|l|l|}
\hline 3. $\begin{array}{l}\text { Lebih suka kegiatan sosial, } \\
\text { daripada melakukan hal } \\
\text { sendiri }\end{array}$ & $\begin{array}{l}\text { 3. Bisa menjadi mediatordalam } \\
\text { perselisihan antart eman }\end{array}$ \\
\hline & $\begin{array}{l}\text { 4. Dapat menyesuaikan dengan } \\
\text { keadaan }\end{array}$ \\
\hline
\end{tabular}

Dari tabel diatas dapat kita simpulkan bahwa gaya belajar interpersonal dan kecerdasan interpersonal saling berkaitan. Jika seorang siswa memiliki kecerdasan interpersonal maka siswa tersebut memiliki gaya belajar interpersonal. Seperti yang telah dikemukakan (Chatib, 2009:90) gaya belajar siswa tercermin dari kecenderungan kecerdasan yang dimiliki oleh siswa tersebut.

\section{Indikator Gaya Belajar Interpersonal}

Dalam penelitian ini peneliti menggunakan indikator kecerdasan interpersonal sebagai acuan melakukan penelitian. Indikator kecerdasan interpersonal pada siswa menurut Gunawan (2005) diantaranya:

1. Membentuk dan mempertahankan suatu hubungan sosial,

2. Mampu berinteraksi dengan orang lain,

3. Mengenali dan menggunakan berbagai cara untuk berhubungan,

4. Mampu mempengaruhi pendapat dan tindakan orang lain

5. Turut serta dalam upaya bersama dan mengambil berbagai peran yang sesuai, mulai dari menjadi pengikut hingga menjadi pemimpin

6. Mengamati perasaan, pikiran, motivasi, perilaku dan gaya hidup orang lain

7. Mengerti dan berkomunikasi dengan efektif baik dalam bentuk verbal maupun non verbal

8. Mengembangkan keahlian untuk menjadi penengah dalam suatu konflik

9. Mampu bekerjasama dengan orang yang mempunyai latar belakang yang beragam

10. Tertarik menekuni bidang yang berorientasi interpersonal, manajemen, atau politik

11. Peka terhadap perasaan, motivasi, dan keadaan mental seseorang

\section{Tingkat gaya belajar interpersonal}

Tingkatan gaya belajar dijelaskan oleh (Tiswan,2016,11) Siswa memiliki gaya belajar interpersonal yang berbeda, dibagi menjadi tiga kategori gaya belajar interpersonal yaitu kategori tinggi, sedang dan juga rendah. Setiap siswa memiliki tingkat gaya belajar interpersonal yang berbeda, hal tersebut adalah hal yang umum dimana ada banyak gaya belajar yang mereka miliki. Gaya belajar interpersonal dengan tingkat yang berbeda akan 
mempengaruhi kehidupan sosialsiswa. Gaya belajar interpersonal tingkat tinggi lebih mampu dalam berkomunikasi dengan guru maupun dengan teman, gaya belajar tingkat sedang bisa dikatakan mampu dalam berkomunikasi dengan guru maupun dengan teman, dan gaya belajar interpersonal tingkat rendah akan kesulitan untuk berkomunikasi baik dengan guru maupun dengan teman sebayanya.

Penelitin akan memberikan angket kepada siswa kelas XI IPA untuk mengetahui berapa banyak siswa yang memiliki tingkat gaya belajar yang tinggi, sedang, dan rendah. Hal tersebut dilakukan untuk mengetahui perbedaan hasil tes soal limit yang diberikan oleh peneliti kepada siswa. Apakah siswa yang memiliki gaya belajar interpersonal tinggi, sedang, atau rendah yang mendapat nilai maksimal.

\section{METODE PENELITIAN}

Dalam metode penelitian diperlukan sebuah pendekatan yang digunakan sebagai dasar dari serangkaian pelaksanaan kegiatan dalam penelitian. Memilih pendekatan tertentu dalam kegiatan penelitian memiliki konsekuensi tersendiri sebagai proses yang harus dikuti secara konsisten dari awal hingga akhir agar memperoleh hasil yang maksimal dan bernilai ilmiah sesuai dengan maksud dari penelitian tersebut.

Melalui penelitian ini, peneliti berusaha mengungkapkan secara mendalam tingkat pemahaman siswa mengenai konsep limit fungsi yang ditinjau dari gaya belajar interpersonal. Data yang dikumpulkan dalam penelitian ini bersifat deskriptif, yaitu penjelasan secara faktual dan aktual bagaimanakah tingkat pemahaman siswa mengenai konsep limit fungsi ditinjau dari gaya belajar interpersonal. Data yang dihasilkan dalam penelitian ini berupa kata-kata yang dipaparkan sebagaimana adanya yang terjadi di lapangan, yang dialami, dirasakan, dan di fikirkan oleh partisipan atau sumber data. Penelitian ini lebih menekankan aktivitas siswa dalam menyelesaikan soal-soal limit fungsi. Proses yang diamati adalah kegiatan siswa selama mengikuti pembelajaran dan kegiatan siswa dalam mengerjakan soal-soal limit fungsi.

Tujuan dari penelitian ini adalah mendeskripsikan tingkat pemahaman siswa mengenai konsep limit fungsi ditinjau dari gaya belajar interpersonal. Sesuai dengan tujuan penelitian tersebut,melalui pendekatan kualitatif dalam penelitian ini,semua fakta baik lisan maupun tulisan dari berbagai sumber data yang didapatkan dari partisipan akan diuraikan sejelas dan seringkas mungkin sehingga benar-benar mampu menjawab permasalahan pada penelitian ini. Oleh karena itu, jenis penelitian iniadalah penelitian deskriptif. Hal ini sejalan dengan pengertian penelitian deskriptif yaitu penelitian yang berusaha mendeskripsikan suatu gejala 
atau peristiwa,kejadian yang terjadi pada saat sekarang. Penelitian deskriptif mengambil masalah atau memusatkan perhatian kepada masalah-masalah aktual sebagaimana adanya pada saat penelitian dilaksanakan.

Untuk subjek penelitian dalam penelitian iniadalah SMA AZ-ZAMIR TANGERANG kelas XI IPA 1, karena pada kelas XI semester genap sedang ditempuh pelajaran mengenai limit fungsi. Data dalam penelitian iniberasal dari hasil tes, wawancara, hasil pengamatan (observasi) yang diolah sedemikian rupa sehingga dapat diketahui gambaran tingkat pemahaman siswa mengenai konsep limit fungsi ditinjau dari gaya belajar interpersonal. Oleh karena itu data yang terkumpul berupa :

1. Jawaban tertulis dari siswa dalambentukangket

2. Jawaban tertulis dari siswa dalam bentuk penyelesaian soal -soal limit fungsi

3. Pernyataan siswa dalam bentuk lisan melalui hasil wawancara secara mendalam

4. Hasil pengamatan (observasi) terhadap siswa selama penelitian berlangsung, meliputi, proses belajar mengajar, aktivitas siswa dalam belajar, sampai pada pelaksanaan tes tertulis.

Dalam penelitian ini peneliti menggunakan beberapa teknik seperti Observasi, Angket/ Kuesioner, Tes, Wawancara, Studi Dokumen, dan Triangulasi. Dalam penelitian kualitatif, yang menjadi instrumen atau alat peneliti adalah peneliti itus endiri. Oleh karena itu peneliti juga harus 'divalidasi' seberapa jauh peneliti siap melakukan penelitian yang selanjutnya dilapangan. Yang melakukan validasia dalah peneliti itu sendiri, melalui evaluasi diri seberapa jauh pemahaman terhadap metode kualitatif, penguasaan teori dan wawasan terhadap bidang yang diteliti, serta kesiapan dan bekal memasuki lapangan.

Sebelum melakukan penelitian di SMA Az Zamir,peneliti melakukan tes uji coba sebanyak 10 soal di SMA Islamic Center Karawaci dengan jumlahsiswa36 siswa.Tesujicobadilakukandisekolah yangberbedakarenadiSMAAzZamir hanyaterdapatsatukelasuntukkelas VIII, sehingga peneliti dengan pertimbangan dosen pembimbing dan gurupembimbingmencarisekolahyang setaradenganSMAAzZamiryaituSMA Islamic Center Karawaci. Uji coba dilakukan untuk mengetahui valid atau tidaknya butir soal akan diuji kepada siswa. 


\section{HASIL DAN PEMBAHASAN}

Dalam melakukan penelitian peneliti melakukan observasi awal sebelum melakukan penelitian, memberikan angket untuk mengetahui tingkat gaya belajar siswa, serta melakukan wawancara kepada siswa yang akan diteliiti. Hal tersebut merupakan cara untuk mengetahui tingkat gaya belajar interpersonal yang mereka miliki apakah tinggi, sedang atau rendah. Setelah memperoleh hasil tingkat gaya belajar interpersonal, peneliti memberikan sebuah tes soal kepada siswa yang akan diteliti. Hasil dari tes tersebut akan menunjukan seberapa mampu siswa memahami konsep limit.

Dalam semua kegiatan maupun itu penelitian ataupun hal yang lain pasti terdapat suatu masalah. Masalah-masalah yang dihadapi peneliti dalam melakukan penelitian merupakan masalah yang wajar, bukan masalah besar. Masalah-masalah yang peneliti hadapi antara lain: 1) Suasana kelas yang ramai, 2) Anak-anak yang susah diatur, dan 3)Siswa tidak mau diwawancarai karena malu. Masalah tersebut merupakan masalah yang wajar, kelas XI IPA memang sudah terkenal sebagai kelas yang ramai, tapi masih bisa sedikit dikendalikan seperti anak-anak pada umumnya. Sebelum melakukan penelitian peneliti sudah melakukan observasi terlebih dahulu, sehingga mengetahu beberapa karakter yang ada di dalam kelas XI IPA.

Dalam penelitian ini peneliti memperoleh hasil yang diinginkan. Hasil dalam sebuah penelitian sangatlah penting. Untuk memperoleh hasil dalam sebuah penelian makan peneliti harus melalui beberapa tahap yang harus dilakukan antara lain:

Dalam kegiatan observasi peneliti bertindak sebagai pengamat. Observasi yang diperoleh peneliti menunjakan bahwa hampir semua siswa kelas XI IPA memiliki gaya belajar interpersonal walau mempunyai tingkat yang berbeda-beda. Dalam satu kelas terlihat bagaimana mereka berteman dan berkomunikasi dengan baik, meskipun ada perbedaan pendapat. Siswa yang memiliki gaya belajar interpersonal lebih aktif di kelas dan membuat suasana kelas menjadi ramai. Hampir semua guru mengatakan bahwa siswa kelas XI IPA adalah kelas paling aktif, aktif dalam segala hal yaitu: dalam hal belajar, kegiatan sekolah, dan aktif dalam bercanda.

Angket gaya belajar interpersonal diberikan dan diisi secara langsung oleh siswa dalam satu kelas.. Adapun interval skor angket gaya belajar Interpersonal adalah sebagai berikut:

Tabel. 1.3. Frekuensi Skor Gaya Belajar Interpersonal

\begin{tabular}{|c|c|c|}
\hline $\begin{array}{c}\text { Interval skor } \\
\text { gaya belajar } \\
\text { interpersonal }\end{array}$ & Kategori & Frekuensi \\
\hline $0-39$ & Rendah & 0 siswa \\
\hline $40-69$ & Sedang & 24 siswa \\
\hline
\end{tabular}




\begin{tabular}{|c|c|c|}
\hline $70-100$ & Tinggi & 3 siswa \\
\hline & Jumlah & 27 siswa \\
\hline
\end{tabular}

Dari tabel di atas dapat dijelaskan bahwa terdapat 3 siswa dengan tingkat gaya belajar interpersonal yang tinggi, 24 siswa dengan tingkat gaya belajar interpersonal yang sedang, dan tidak ada siswa dengan tingkat gaya belajar interpersonal yang rendah. Pada awal penelitian peneliti akan mengambil sampel 3 siswa dengan tingkat gaya belajar interpersonal tinggi, 3 siswa dengan tingkat gaya belajar interpersonal sedang, dan 3 siswa dengan tingkat gaya belajar rendah. Dari hasil yang diperoleh dalam pengisian angket hanya diperoleh 2 tingkat gaya belajar interpersonal yaitu tinggi dan sedang, maka peneliti mengambil sampel 6 siswa terdiri dari 3 siswa dengan tingkat gaya belajar interpersonal yang tinggi, dan 3 siswa dengan tingkat gaya belajar interpersonal yang sedang karena tidak ada siswa dengan gaya belajar tingkat interpersonal rendah. Keenam siswa tersebut akan mengikuti tes soal limit dan wawancara.

Tes yang dilakukan oleh peneliti yaitu dengan cara memberikan 6 butir soal dengan tingkat kesulitan yang berbeda di setiap butir soal. Soal diberikan kepada 3 siswa dengan tingkat gaya belajar tinggi dan 3 siswa dengan tingkat gaya belajar sedang. Karena dalam satu kelas hanya terdapat gaya belajar interpersonal tingkat tinggi dan sedang. Nama-nama siswa dengan tingkat gaya belajar tinggi dan sedang ada pada tabel di bawah ini:

Tabel 1.4. Nama siswa yang mengikuti tes soal

\begin{tabular}{|c|c|}
\hline $\begin{array}{c}\text { Tingkat gaya belajar } \\
\text { interpersonal }\end{array}$ & Nama \\
\hline \multirow{2}{*}{ Tinggi } & $\mathrm{AD}$ \\
\cline { 2 - 2 } & $\mathrm{AN}$ \\
\cline { 2 - 2 } & $\mathrm{IS}$ \\
\hline \multirow{2}{*}{ Sedang } & $\mathrm{SA}$ \\
\cline { 2 - 2 } & $\mathrm{PRS}$ \\
\cline { 2 - 2 } & $\mathrm{TLV}$ \\
\hline
\end{tabular}

Wawancara yang dilakukan oleh peneliti yaitu, wawancara yang dilakukan kepada guru dan siswa. Peneliti mewawancarai guru matematika sekaligus wali kelas dari kelas XI IPA yaitu ibu Sm, serta 3 siswa dengan tingkat gaya belajar yang tinggi yaitu Ad, An, Is, dan 3 siswa dengan tingkat gaya belajar yang sedang yaitu Sa, Prs, dan Tlv. Berdasarkan hasil wawancara dengan guru matematika sekaligus wali kelas XI IPA diperoleh hasil bahwa siswa kelas XI IPA sangat aktif, hampir semua siswa memiliki gaya belajar interpersonal. Dengan cara belajar kelompok dan aktif di dalam walaupun di luar kelas.

Prima, Vol. 1, No. 1, Juli 2017, 157-173. 
Dalam mendukumentasikan penelitian peneliti mengambil beberapa gambar siswa di dalam kelas maupun di luar kelas, gambar saat para siswa mengisi angket, mengerjakan soal limit, saat murid dan guru melakukan wawancara. Peneliti juga merekam percakapan antara peneliti dan subjek penelitian.

Dalam memahami konsep limit siswa harus mampu memahami kalkulus. Tidak semua siswa yang memiliki gaya belajar interpersonal mampu memahami konsep limit. Siswa yang memiliki gaya belajar interpersonal belum tentu selalu aktif dalam belajar, bisa jadi mereka aktif dalam hal yang lain. Hal tersebut dapat dilihat dari hasil tes yang diperoleh para siswa dengan tingkat gaya belajar masing-masing. Siswa yang benar-benar aktif dalam belajar akan dapat memahami konsep limit dengan baik, berbeda dengan anak yang kurang aktif dalam belajar tetapi lebih aktif dalam berbicara.

Gaya belajar interpersonal cenderung membuat suasana menjadi ramai. Hal tersebut merupakan salah satu masalah yang peneliti alami saat melakukan penelitian, dimana para siswa lebih aktif. Beberapa masalah yang dialami peneliti saat awal sampai akhir penelitian yaitu:

1. Suasana kelas yang ramai

Saat pertama peneliti membagikan angket untuk mengetahui tingkat gaya belajar interpersonal, siswa kurang begitu tenang dalam mengisinya, mungkin karena cara belajar mereka atau mungkin karna suasana kelas yang panas. Seperti percakapan wawancara antara peneliti dengan siswa sebagai berikut:

Table 1.5. wawancara peneliti dan siswa

\begin{tabular}{|c|c|c|}
\hline Pertanyaan & Narasumber & Catatan \\
\hline $\begin{array}{l}\text { Apakah suasana } \\
\text { sekolah cukup } \\
\text { nyaman? }\end{array}$ & Ad & $\begin{array}{l}\text { Panas, nggak } \\
\text { nyaman di } \\
\text { kelas }\end{array}$ \\
\hline
\end{tabular}

Hal tersebut menjadi salah satu penyebab suasana kelas menjadi ramai dan tidak kondusif.

2. Anak-anak yang susah diatur

Selain suasana kelas yang ramai, siswa kelas XI sangat susah untuk diatur jadi membutuhkan kesabaran yang lebih. Seperti yang jelaskan oleh ibu Ning saat melakukan wawancara

Bu Sm :" Kadang kalo ruangannya lagi panas juga ngaruh terus 
ee apa lagi tu ee ruangan biasanya sih, trus ama anak yang memang seneng bikin gaduh tu susah"

Jadi ada beberapa anak yang memang sering membuat suasana menjadi gaduh, sehingga membuat siswa susah diatur.

3. Siswa tidak mau diwawancarai karena malu

Masalah terakhir yang dihadapi peneliti yaitu saat memilih siswa untuk dapat melakukan wawancara. Peneliti akan mewawancarai 3 siswa dari 3 siswa dengan tingkat gaya belajar yang tinggi dan 3 siswa dari 24 siswa dengan tingkat gaya belajar yang sedang. 3 siswa dengan tingkat gaya belajar tinggi bersedia melakukan wawancara, sedangkan dari 24 siswa yang memiliki tingkat gaya belajar interpersonal sedang merasa malu dan tidak mau untuk melakukan wawancara kecuali Sa

Peneliti mengumpulkan semua data untuk memproleh suatu hasil. Data yang dikumpulkan peneliti berupa hasil dari observasi, angket, tes soal dan wawancara. Observasi yang diperoleh peneliti menunjukan bahwa siswa kelas XI IPA termasuk kelas dengan siswa yang sangat aktif. Dimana siswa yang memiliki gaya belajar interpersonal cenderung aktif sehingga dalam satu kelas terdapat siswa yang memiliki gaya belajar interpersonal. Gaya belajar interpersonal siswa kelas XI IPA memiliki tingkat yang berbeda pada setiap siswanya, hal tersebut dapat dilihat dari hasil angket.

Dari hasil angket yang diperoleh siswa kelas XI IPA memiliki tingkat gaya belajar interpersonal tinggi dan sedang. 3 siswa dengan tingkat gaya belajar interpersonal tinggi dan 24 siswa dengan tingkat gaya belajar interpersonal sedang, hasil tersebut dapat dilihat pada lampiran skor angket kelas XI IPA. Dalam penelitian ini peneliti mengambil sampel 6 siswa, 3 siswa dengan tingkat gaya belajar interpersonal tinggi yaitu Ad, An, Is dan 24 siswa dengan tingkat gaya belajar interpersonal sedang. Peneliti harus memilih 3 dari 24 siswa dengan gaya belajar interpersonal sedang. Seperti yang dijelaskan dalam masalah-masalah yang dialami peneliti, saat memilih sampel peneliti ada sedikit hambatan dikarenakan mereka merasa malu untuk melakukan wawancara. Pada akhirnya peneliti memilih Sa, Prs, dan Tlv. Peneliti memilih Sa karena siswa tersebut aktif dalam belajar maupun hal sosial tetapi dalam mengisi angket mendapat kategori sedang. Prs merupakan siswa yang sering dijahili di kelas dan ada yang kurang suka dengan Prs, seperti wawancara berikut:

Prima, Vol. 1, No. 1, Juli 2017, 157-173. 
Table 1.6. wawancara peneliti dan siswa

\begin{tabular}{|l|c|l|}
\hline Pertanyaan & Narasumber & \multicolumn{1}{|c|}{ Catatan } \\
\hline $\begin{array}{l}\text { Siapa orang } \\
\text { yang paling }\end{array}$ & & $\begin{array}{l}\text { Yang nggak } \\
\text { saya sukain, ada } \\
\text { kamu tidak } \\
\text { sukai di }\end{array}$ \\
\cline { 2 - 3 } $\begin{array}{l}\text { sekolah?ken aja, itu } \\
\text { nyerocos aja }\end{array}$ \\
apa?
\end{tabular}

Moon yang dimaksud oleh Ad adalah Prs, dimana Prs dianggap siswa yang banyak bicara. Dan yang terakhir Tlv, Tlv dipilih peneliti karena mendapat skor angket yang dia miliki cukup rendah walau masih dalam kategori sedang, dan Tlv bersedia untuk melakukan waawancara.

Dalam penelitian ini peneliti memperoleh hasil seberapa mampu siswa memahami konsep limit yang ditinjau dari gaya interpersonal mereka. Kita dapat melihat seberapa mampu mereka memahami konsep limit dari hasil tes soal yang diperoleh 6 siswa dengan tingkat gaya belajar interpersonal yang berbeda. Hasil tes soal yang diperoleh menunjukan bahwa siswa dengan gaya belajar tingkat tinggi lebih baik dari gaya belajar tingkat sedang. Enam orang siswa telah mengerjakan tes soal limit yang diberikan oleh peneliti dan memperoleh hasil seperti tabel dibwah ini:

Tabel 1.7 Hasil Tes Soal

\begin{tabular}{|c|c|c|}
\hline $\begin{array}{c}\text { Tingkat gaya } \\
\text { belajar } \\
\text { interpersonal }\end{array}$ & Nama & Nilai \\
\hline \multirow{2}{*}{ Tinggi } & $\mathrm{Ad}$ & 70 \\
\cline { 2 - 3 } & $\mathrm{An}$ & 65 \\
\cline { 2 - 3 } & $\mathrm{Is}$ & 55 \\
\hline \multirow{2}{*}{ Sedang } & $\mathrm{Sa}$ & 58 \\
\cline { 2 - 3 } & $\mathrm{Prs}$ & 20 \\
\cline { 2 - 3 } & $\mathrm{Tlv}$ & 45 \\
\hline
\end{tabular}

Tabel diatas menunjukan bahwa siswa dengan tingkat gaya belajar interpersonalnya tinggi mampu mendapatkan nilai diatas anak yang tingkat gaya belajar interpersonalnya sedang. Dalam tabel tersebut juga menunjukan bahwa ada perbedaan hasil tes antara gaya belajar interpersonal tingkat tinggi dan sedang antara Is dan Sa. Sa memperoleh hasil lebih tinggi daripada Is. Hasil tersebut menunjukan bahwa tidak semua anak dengan gaya belajar interpersonal tinggi mampu memahami konsep limit. Anak yang memiliki gaya belajar interpersonal belum tentu selalu aktif dalam pelajaran misalnya suka belajar kelompok, saling tukar pikiran, aktif dalam bertanya. Ada juga anak dengan gaya belajar interpersonal tinggi tetapi kurang mampu memahami konsep limit, karena anak tersebut lebih aktif bercanda di dalam kelas dibanding aktif belajar. Dengan kata lain siswa dengan gaya belajar interpersonal 
yang tinggi belum tentu mampu memahami konsep limit. Setiap siswa memiliki tingkat gaya belajar yang berbeda-beda, tidak semua siswa memiliki tingkat gaya belajar interpersonal tinggi bisa memahami konsep limit.

Hasil yang diperoleh dalam wawancara guru dan siswa. Dalam wawancara bu Sm menjelaskan tentang gaya belajar interpersonal, yaitu

Bu Sm "Gaya belajar interpersonal adalah gaya belajar dalam mengerjakan berkelompok, diskusi”.

Beliau juga menjelaskan bahwa ada dampak positif dan negatif dalam menggunakan gaya belajar interpersonal

$\mathrm{Bu} \mathrm{Sm}$ “Ada dampak positif dan negatifnya yang seperti saya bilang, dampak positifnya ya anak yang nggak tau menjadi tau karnakan mereka nanya ketemennya jadi lebih enak dengan temennya kali ya, namanya sama gurunya mungkin ada yang malu gitu kan, dan yang kalo dampak negatifnya ya kalo anaknya yang pendiem ya diem saja, ya saya akal-akalin aja lah emmm... saya bilang keanak-anak yang gak ikut mengerjakan eee,,, tidak usah masukan kedalam kelompoknya nanti biar nggak dapet nilai, mau nggak mau mereka ikut mengerjakan gitu kan".

Gaya belajar interpersonal identik dengan belajar kelompok. Kebanyakan siswa suka belajar kelompok, tapi ada juga yang suka belajar mandiri dengan alasan yang berbeda-beda. Seperti hasil wawancara 6 siswa dengan pertanyaan "Jika disuruh memilih kalian akan memilih diskusi kelompok atau belajar mandiri? Mengapa?" jawaban siswa:

Table 1.8. hasil wawancara siswa

\begin{tabular}{|c|c|}
\hline Narasumber & Catatan \\
\hline $\mathrm{Ad}$ & $\begin{array}{l}\text { Mandiri bisa, kelompok bisa. } \\
\text { Kalo kelompok bisa ngerjain } \\
\text { bareng-bareng kalo mandiri mikir } \\
\text { sendiri. }\end{array}$ \\
\hline An & $\begin{array}{l}\text { Kelompok, karna bisa ngebantuin } \\
\text { kalo nggak bisa. }\end{array}$ \\
\hline Is & $\begin{array}{l}\text { Mandiri bu, karna biar makin } \\
\text { kedepan makin bagus }\end{array}$ \\
\hline $\mathrm{Sa}$ & $\begin{array}{l}\text { Kelompok, dikarenakan kalo } \\
\text { kelompok itu kita tau kesalahan } \\
\text { kita dimana dan letak kesalahan } \\
\text { seseorang juga dimana }\end{array}$ \\
\hline Prs & $\begin{array}{l}\text { Diskusi kelompok, soalnya kalo } \\
\text { mandiri aku bingung mau nanya } \\
\text { sama siapa }\end{array}$ \\
\hline Tlv & $\begin{array}{l}\text { Belajar mandiri, karna kalo } \\
\text { belajar mandiri itu lebih kitanya } \\
\text { gerak gitu dari pada belajar } \\
\text { kelompok kalo kelompokkan } \\
\text { biasanya diskusi ya diskusi gitu, } \\
\text { jadi ujung-ujungnya ngobrol }\end{array}$ \\
\hline
\end{tabular}

Prima, Vol. 1, No. 1, Juli 2017, 157-173. 
Dari pernyataan diatas dapat disimpulkan bawa ada dampak positif dan negatif seperti yang telah diutarakan oleh ibu Sm. Belajar kelompok bisa jadi tempat bertukar pikiran bisa juga jadi tempat mengobrol.

Dari semua data yang diperoleh menujukan bahwa tidak semua siswa dengan tingkat gaya belajar interpersonal tinggi lebih mampu memahami konsep limit. Hal tersebut dapat dilihat dari hasil tes soal yang mereka peroleh. Siswa dengan gaya belajar interpersonal tingkat tinggi mendapat nilai dibawah siswa dengan tingkat gaya belajar interpersonal sedang yaitu Is mendapat nilai 55 dan Sa mendapat nilai 58. Is merupakan anak yang sering memulai keributan di dalam kelas, lebih banyak bicara dan bermain. Hubungannya dengan guru juga tidak terlalu baik, seperti dalam wawancara berikut:

Table 1.9. hasil wawancara siswa

\begin{tabular}{|l|c|l|}
\hline \multicolumn{1}{|c|}{ Pertanyaan } & Narasumber & Catatan \\
\hline Bagaimana & Is & Alhamdulillah \\
hubunganmu & & , agak buruk \\
dengan guru? & & \\
\hline
\end{tabular}

Dari hasil wawancara tersebut menunjukan bahwa Is bukan termasuk anak yang rajin belajar, dimana Is hanya aktif dalam bercanda di dalam kelas. Jadi tidak semua siswa yang memiliki tingkat gaya belajar interpersonal tinggi mampu memahami konsep limit. Ad dan An merupakan siswa dengan gaya belajar tingkat tinggi yang mampu memahami konsep limit sedangkan Is tidak, hal tersebut membuktikan bahwa tidak semua siswa dengan tingkat gaya belajar yang tinggi mampu memahami konsep limit.

\section{SIMPULAN DAN SARAN}

Berdasarkan hasil yang diperoleh dalam penelitian, maka peneliti dapat menarik kesimpulan, yaitu

Gaya belajar interpersonal siswa kelas XI IPA AZ-ZAMIR memiliki 2 tingkat yaitu, tingkat gaya belajar interpersonal tinggi dan tingkat gaya belajar interpersonal sedang. 3 siswa dengan tingkat gaya belajar interpersonal tinggi dan 3 siswa dengan tingkat gaya belajar interpersonal sedang. 2 siswa dengan tingkat gaya belajar interpersonal tinggi mampu memahami konsep limit dan 1 siswa dengan tingkat gaya belajar interpersonal tinggi tidak dapat memahami konsep limit, sedangkan 3 siswa dengan tingkat gaya belajar sedang tidak 
dapat memahami konsep limit, hal ini menunjukan bahwa tidak semua siswa dengan tingkat gaya belajar interpersonal tinggi mampu memahami konsep limit.

Berdasarkan kesimpulan diatas, peneliti dapat menyampaikan saran sebagai berikut: 1) Guru dapat melihat bagaimana cara siswa belajar, dan bagaimana cara agar mereka mampu memahami konsep limit; 2) Siswa perlu membentuk kelompok belajar, karna siswa bisa bertukar pikiran dan yang tidak tahu menjadi tahu.

\section{DAFTAR PUSTAKA}

Adi M. Gunawan. (2005). Born To Be Genius. Jakarta: Gramedia Pustaka Utama.

Chatib, munif. (2009). Sekolahnya Manusia. Bandung: Kaifa

Silver, H. F., Brunsting, J. R., Walsh, T., \& Thomas, E. J. (2013). Pengajaran Matematika, Kurikulum Inti Bersama, Seri Pengajaran Tematik Integratif. Jakarta: Pt. Indeks.

Sugiyono. (2012). Metode Penelitian Pendidikan (Pendekatan Kuantitatif, Kualitatif, dan $R \& D)$. Bandung: Alfabeta.

\section{Online journal:}

Ferriman, Justin. (2013). 7 Major Learning Styles - Which One are You?. https://www.learndash.com/7-major-learning-styles-which-one-is-you/. diakses 13 Mei 2017

Hartati, Leny. (2016). Pengaruh Gaya Belajar Dan Sikap Siswa Pada Pelajaran Matematika Terhadap Hasil Belajar Matematika. Jurnal Formatif 3(3): 224-235 ISSN:2088-351X

Hasrul. (2009). Pemahaman Tentang Gaya Belajar. Jurnal MEDTEK, Volume 1, Nomor 2, Oktober 2009

Irwan, dkk. (2012) Pemahaman Konsep Matematika Pada Materi Turunan Melalui Pembelajaran Teknik Probing. Vol. 1 No. 1 (2012) : Jurnal Pendidikan Matematika, Part 2 : Hal. 68-72.

Junairi Rahmat, Suherman, Putra Atus Amadi (2014) Penerapan Lembar Kerja Siswa Berbasis Gaya Belajar Mastery, Interpersonal, Understanding, Dan Self-Expressive Di Kelas Vii Kecerdasan Interpersonal Smp Negeri 7 Padang Tahun Pelajaran 2013/2014. Vol. 3 No. 2 (2014) : Jurnal Pendidikan Matematika, Part 1 : Hal. 49-53

Lestaria, Yunika, Ningsih. (2016). Kemampuan Pemahaman Konsep Matematika Mahasiswa Melalui Penerapan Lembar Aktivitas Mahasiswa (LAM) Berbasis Teori Apos Pada Materi Turunan. Edumatica Volume 06 Nomor 01 April 2016, ISSN: 2088-2157 
Murizal Angga, Yarman, Yerizon. (2012) Pemahaman Konsep Matematis Dan Model Pembelajaran Quantum Teaching. Vol. 1 No. 1 (2012) : Jurnal Pendidikan Matematika Hal. 19-23

Napitupulu, Efendi. (2014). Pengaruh Strategi Pembelajaran Terhadap Hasil Belajar Pendidikan Kewarganegaraan. Vol. 7, No. 1, April 2014, p-ISSN: 1979-6692; e-ISSN: $2407-7437$

Pujihastuti, Isti. (2010). Prinsip Penulisan Kuesioner Penelitian. CEFARS : Jurnal Agribisnis dan Pengembangan Wilayah Vol. 2 No. 1 Desember 2010

Putra, Okven Pratama. (2013). Memahami cara belajar anak dengan Multiple Intelligence.http://jurnalilmiahtp2013.blogspot.co.id/2013/12/mamahami-cara-belajaranakdengan.html. diakses 05 April 2017

Rohmah Emay Aenu, Wahyudin. (2016). Pengaruh Model Pembelajaran Kooperatif Tipe Teams Games Tournament (Tgt) Berbantuan Media Game Online Terhadap Pemahaman Konsep Dan Penalaran Matematis Siswa. EduHumaniora: Jurnal Pendidikan Dasar | ISSN 2085-1243 Vol. 8. No.2 Juli 2016 | Hal 126-143

\section{Theses, Dissertation:}

Fitriana, Laela. (2013). Analisis Pemahaman Siswa Mengenai Konsep Limit Fungsi Berdasarkan Teori APOS Ditinjau dari Gaya Kognitif (Field Dependent dan Field Independent) di Kelas XI IPA 2 MAN Rejotangan Tahun 2012/2013. Skripsi, Program Studi Tadris Matematika, Jurusan Tarbiyah, Sekolah Tinggi Agama Islam (STAIN) Tulungagung.

Handini, Risa. (2013) Kecerdasan Interpersonal Pada Siswa Kelas IV SD Negeri Kembaran Kulon I. Universitas Negeri Yogyakarta.

Rayesh, Emir Eka Putra. (2016). Hubungan Gaya Belajar Dengan Multiple Intelegences Siswa Berprestasi Kelas IV dan V SD/MI Di Kota Malang. Malang: Universitas Islam Negeri Maulana Mailik Ibrahim Malang. 